\title{
'Swinging on the Anchor'
}

\section{The Difficulties in Achieving Greenhouse Gas Abatement in Shipping Via Virtual} Arrival

Poulsen, René Taudal ; Sampson, Helen

Document Version

Accepted author manuscript

Published in:

Transportation Research. Part D: Transport \& Environment

DOI:

10.1016/j.trd.2019.07.007

Publication date:

2019

License

CC BY-NC-ND

Citation for published version (APA):

Poulsen, R. T., \& Sampson, H. (2019). 'Swinging on the Anchor': The Difficulties in Achieving Greenhouse Gas Abatement in Shipping Via Virtual Arrival. Transportation Research. Part D: Transport \& Environment, 73, 230244. https://doi.org/10.1016/j.trd.2019.07.007

Link to publication in CBS Research Portal

\section{General rights}

Copyright and moral rights for the publications made accessible in the public portal are retained by the authors and/or other copyright owners and it is a condition of accessing publications that users recognise and abide by the legal requirements associated with these rights.

\section{Take down policy}

If you believe that this document breaches copyright please contact us (research.lib@cbs.dk) providing details, and we will remove access to the work immediately and investigate your claim. 


\section{'Swinging on the Anchor': The Difficulties in Achieving Greenhouse Gas Abatement in Shipping Via Virtual Arrival \\ René Taudal Poulsen, and Helen Sampson}

Journal article (Accepted manuscript*)

\section{Please cite this article as:}

Poulsen, R. T., \& Sampson, H. (2019). 'Swinging on the Anchor': The Difficulties in Achieving Greenhouse Gas Abatement in Shipping Via Virtual Arrival. Transportation Research. Part D: Transport \& Environment, 73, 230244. https://doi.org/10.1016/j.trd.2019.07.007

00l: https://doi.org/10.1016/j.trd.2019.07.007

* This version of the article has been accepted for publication and undergone full peer review but has not been through the copyediting, typesetting, pagination and proofreading process, which may lead to differences between this version and the publisher's final version AKA Version of Record.

Uploaded to CBS Research Portal: August २०२०

(C) 2019. This manuscript version is made available under the CC-BY-NC-ND 4.0 license http://creativecommons.org/licenses/by-nc-nd/4.0/ 


\title{
'Swinging on the anchor': the difficulties in achieving greenhouse gas abatement in shipping via virtual arrival
}

\section{René Taudal Poulsen and Helen Sampson}

\begin{abstract}
The abatement of greenhouse gas emissions represents a major global challenge and an important topic for transportation research. Several studies have argued that energy efficiency measures for virtual arrival and associated reduced anchorage time can significantly reduce emissions from ships by allowing for speed reduction on passage. However, virtual arrival is uncommon in shipping. In this paper, we examine the causes for waiting time for ships at anchor and the limited uptake of virtual arrival. We show the difficulties associated with the implementation of virtual arrival and explain why shipping is unlikely to achieve the related abatement potential as assumed by previous studies. Combining onboard observations with seafarers and interviews with both sea-staff and shore-based operational personnel we show how charterers' commercial priorities outweigh the fuel saving benefits associated with virtual arrival. Moreover, we demonstrate how virtual arrival systems have unintended, negative consequences for seafarers in the form of fatigue. Our findings have implications for the IMO's greenhouse gas abatement goals.
\end{abstract}

Keywords: Greenhouse gas abatement; Energy efficiency; Virtual arrival; Speed optimization; Waiting time

\section{Highlights}

- We study efficiency measures for greenhouse gas emission abatement in shipping

- We explain why ships wait at anchor and why virtual arrival is uncommon

- We show how cargo-owners' decisions increase emissions from shipping

- We show that commercial priorities outweigh fuel saving benefits of virtual arrival

- We describe how virtual arrival systems may increase seafarer fatigue

\section{Introduction}

The reduction of greenhouse gas emissions (GHG) from the international shipping industry is a major business/policy challenge and an important research topic (e.g., Smith et al. 2014; Bows-Larkin 2015; Lister et al. 2015; Petitt et al. 2018; Psaraftis 2018). In 2012, the international shipping industry accounted for approximately 2.1 per cent of anthropogenic GHG emissions (Smith et al. 2014), and the United Nations' International Maritime Organization (IMO) recently set two goals for significant emissions abatement. By 2030, the industry should reduce its emissions 'per transport work' by 40 per cent (relative to 2008), and by 2050 it should halve absolute emissions (compared to 2008) (IMO 2018).

The use of both energy efficiency measures (e.g., Faber et al. 2011; Eide et al. 2011; Johnson et al. 2013; Rehmatulla 2014; Poulsen and Sornn-Friese 2015; Poulsen and Johnson 2016; Viktorelius and Lund 2019; Knorring 2019) and alternative fuels (e.g., Brynolf et al. 2014; Rojon \& Dieperink 2014) have been proposed to abate emissions. Eide et al. (2009), Bazari and Longva (2011), Faber et al (2011), Johnson and Styhre 
(2015), Jia et al. (2017), and Andersson and Ivehammar (2017), have all pointed to significant potential for emissions' abatement through increased voyage efficiency (i.e. travel at the minimum speed necessary). Generally speaking, a ship's fuel consumption is linearly related to the third or fourth power of the speed (Faber et al. 2011; IMO 2016). ${ }^{1}$ Speed reductions can therefore significantly reduce fuel consumption and air emissions. The IMO has also emphasized this in its guidance to ship-owners (IMO 2009, 2018).

Reduced waiting time would appear to represent a win-win for business and the environment, because slower voyages should result in lower costs and air emissions without adverse effects on transportation capacity or time (Faber et. 2011; Jia et al. 2017). Notwithstanding the automatic benefits that come with reduced fuel consumption at lower speeds, however, ships still arrive at ports 'early' and spend time waiting at anchor (Johnson and Styhre 2015, Jia et al. 2017). In 2009, a tanker shipping vice president summarized the paradox associated with waiting time at anchorage in the following way: "So the ships hurry to the port and sit there and wait, sometimes for weeks. We hurry to wait." (Lloyd's List 2009). This suggests that whilst it would be feasible for ships to slow down and consume less fuel that is currently not what is happening.

In recent years, charterers and shipping companies have tried to implement just-in-time arrivals with help of the 'virtual arrival system'. In 2009, BP Shipping pioneered virtual arrival with Maersk Tankers on the tanker Bro Elizabeth (Maersk 2009; BP/Maersk 2010; BP 2011). In the voyage charter party the two parties included a virtual arrival clause. When it became evident that the oil terminal could not accommodate the tanker at the originally expected time, the clause enabled the ship to slow down and postpone arrival by 27 hours. Under this arrangement the vessel was deemed to have arrived 'virtually' at the originally agreed time. This allowed the ship-owner to earn demurrage from the charterer for the longer than expected use of the ship. A third party weather routing service verified the updated schedule and route. BP and Maersk estimated fuel savings in the range of 27 per cent (equivalent to 183.2 metric tons of $\mathrm{CO}_{2}$ ) from slowing down the vessel, and shared the bunker savings of USD 24,800 equally. For the ship-owner this represented a 6 percent improvement in earnings, and the charterer saved 3 percent on the freight bill. In their promotion of virtual arrival, BP and Maersk concluded: "There is no loser with Virtual Arrival." (BP/Maersk 2010, p. 10).

The principles of virtual arrival were further explored by BIMCO, a global ship-owner association with extensive legal expertise in charter parties. BIMCO developed a virtual arrival clause, which ship-owners and charters could include in voyage charter parties (BIMCO 2013) and a slow-steaming clause for time charters (BIMCO 2011) to allow for speed optimization while en route. At the same time the shipping press embraced virtual arrival with enthusiasm (Lloyd's List 2010, 2011a, 2011b). Intertanko (a global tankerowners' association) also advised its member to use virtual arrival (Intertanko/OCIMF 2010), and hosted a virtual arrival launching event in the presence of the EU Commissioner for Transport in 2011 (Intertanko 2011). However, several years later, virtual arrival remains uncommon (Lloyd's List 2016, 2019), and this begs the question - why?

The occurrence of waiting time in an industry with intense price competition, low profit margins and strong cost pressures (Stopford 2009, UNCTAD 2018) is remarkable and the causes of such apparent inefficiencies

\footnotetext{
${ }^{1}$ Strictly speaking, the speed-fuel consumption curve is U-shaped. Ships have high fuel consumption at very low speed, because they encounter high wind and wave resistance.
} 
deserve more attention within transportation research. Following calls by Johnson and Styhre (2015) and Adland and Jia (2018), we explore the difficulties in achieving air emission abatement via virtual arrival, and investigate the following two related research questions: Why do ships wait at anchorage? and Why is the uptake of virtual arrival in shipping so limited? We focus on tankers and dry bulk ships, which represented 71.5 per cent of the world fleet (in terms of deadweight tonnage) in 2017 and accounted for approximately the same share of GHG emissions from shipping in 2012 (Smith et al. 2014). They predominantly operate as tramps, i.e. "taxi services" of the sea. In contrast the scheduled liner services for container ships and ferries represent "bus services" of the sea (UNCTAD 2018). Several studies (e.g., Golias et al. 2009; Corbett et al. 2009; Du et al. 2011; Qi and Song 2012; Lalla-Ruiz et al. 2018) have investigated the potential for speed and port time optimization in liner shipping. Viktorelius and Lund (2019) also did an ethnographic study on the potential for energy efficiency onboard five ropax vessels, which operate in ferry services. However, the results from liner shipping are not transferrable to tramp shipping, where the trading patterns, cargo operations and commercial conditions are fundamentally different.

In this paper we: review the literature on virtual arrival, port time and speed choice in tanker and dry bulk shipping, and elaborate on the research gap which we address; present our methods; discuss causes for the limited uptake up virtual arrival and the causes waiting at anchorage and in port; and engage with the existing literature. Finally, we summarize our findings in the conclusion, and discuss the policy implications.

\section{Literature review}

Speed optimization has attracted considerable attention amongst academics (Cariou 2011, Mander 2017; Psaraftis 2019) who have identified its benefits. "Slow-steaming" occurs in response to rising fuel costs and depressed freight rates (Chang and Wang 2014; Psaraftis 2019). Extending transit times and decreasing a vessel's productivity, slow-steaming is feasible with simple engine load reductions. More complicated retrofit measures such as bulbous bow and main engine modifications have also been employed by shipowners to optimize ships for lower service speeds (e.g., Lloyds' List 2018). However, Adland and Jia (2018) showed that fuel prices and freight rates were not good predictors of the service speeds for capesize dry bulk carriers in the period 2011-12. Ships did not reduce speed despite high fuel costs and low freight rates, indicating that other constraints might affect speed choice. They attributed the counterintuitive findings to weather conditions and charter party clauses.

In contrast to slow-steaming, energy efficiency measures for virtual arrival and reduced waiting time do not extend transportation times or reduce annual transport capacity. They just minimize time at anchorage, and therefore allow for lower voyage speeds. Corbett et al. (2009), Bazari and Longva (2011), Eide et al. 2011, Faber et al. (2011), Rehmatulla and Smith (2015), and Johnson and Styhre (2015) see reduced waiting time in anchorage/port as a cost-effective energy efficiency measure. Eide et al. (2011) found that reduced waiting time was amongst the most cost-effective of all fuel saving measures and Faber et al. (2011) estimated a fuel saving potential of up to 10 per cent. Johnson and Styhre (2015) studied the port turnaround time for two dry bulk ships trading in European short-sea trades and estimated that a reduction in port time of one to four hours could lead to fuel savings of up to 8 percent for vessels in these trades. Andersson and Ivehammar (2017) analyzed waiting time at anchor for vessels in the Baltic Sea in 2015 and identified significant fuel saving potential, in particular for tankers. They based their analysis on highgranular ship-position data sets from the Automated Identification System (AIS). Jia et al. (2017) also used AIS-data sets to analyze the waiting times for 483 Very Large Crude Carriers (VLCCS) during the period 2013- 
15. They concluded that "... fuel savings can range from $7.26 \%$ with only a $25 \%$ reduction in 'excess' port time, to $19 \%$ if all apparent inefficiencies can be removed" (Jia et al. 2017, p. 57), and argued "...that there is a substantial untapped environmental benefit from forcing the implementation of a VA [Virtual Arrival] policy at the global level in place of the current First-come-first-served port policies" (Jia et al. 2017, p. 57). They proposed that the IMO and EU should consider policy measures to address this.

Although some researchers have touched on virtual arrival and the importance of collaboration between stakeholders, including port authorities, in its implementation (Gibbs et al. 2014, Poulsen et al. 2018), the reason why virtual arrival has not been implemented more broadly has not been given close attention. Charter parties frequently incentivize on time arrival (Panayides 2018) but virtual arrival systems seem in theory to address the pressures that these would otherwise exert on ship operators in terms of arrival times. However, that seems not to be the case and this requires further investigation. Our study sheds light on the reasons why virtual arrival has not been implemented in shipping and the broader implications of these for policy discussions on how to achieve the IMO's GHG goals.

\section{Methods}

In our exploration of two why questions, we employed two qualitative research methods in this research. We conducted semi-structured interviews (Kvale and Brinkmann 2009) with shipping company managers in order to explore their perceptions of why virtual arrival was not being requested by clients and to discover whether it was ship operators themselves who were creating barriers to virtual arrival. We also undertook non-participant observation (Kristiansen and Krogstrup 1999) onboard two tankers for a total of 37 days in order to understand the perspective of seafarers and the operational considerations that might present barriers to the uptake of virtual arrival.

\subsection{Interviews}

We interviewed 30 top and middle managers in 18 shipping companies' chartering, operations and technical departments (Table 1). The chartering managers are particularly relevant for the question of uptake of virtual arrival. Given the experience of the Bro Elizabeth (and the high \% savings achievable by ship operators) it would be reasonable to expect that the chartering managers employed by ship operators might be key in encouraging the uptake of virtual arrival agreements. They find employment for the company's vessels and negotiate contractually with charterers. In tanker shipping, charterers are mainly oil majors and trading houses. In dry bulk shipping, the group is more diverse, including commodity traders, power plants, mines and agro-businesses. The operations' managers' experiences are highly relevant for understanding causes for waiting time in port and at anchorage. They advise the masters about voyages, and provide speed instructions. They also monitor ship performance relative to charter party specifications and track the time used for different phases of the voyage. If delays occur, operations' managers calculate the economic compensation due to the affected party. Finally, the technical managers are responsible for technical operations and monitor each ship's fuel consumption. They typically have backgrounds as naval architects, master mariners or marine engineers. In contrast to the commercial departments of chartering and operations, many of the technical managers have seafaring experience of their own, which is highly relevant for the questions pertaining to waiting time.

PLEASE ADD TABLE 1 HERE 


\section{Table 1. Interviewees}

We carried out interviews in 2012-13 and 2018. The first period coincided with high bunker prices and depressed freight rates. Ship-owners had strong economic incentives to employ virtual arrival and reduce waiting time to lower fuel costs. Our interviews occurred shortly after BP had pioneered virtual arrival. In 2018 , bunker prices had fallen, but were exhibiting a renewed upwards trend. Tanker and dry bulk freight markets remained depressed due to excess capacity.

The first period of interviews focused on the potential for fuel savings, and considered speed optimization, voyage execution and virtual arrival (The interview guide is reproduced in [anonymized for peer review]). Building on our initial findings, in 2018 we concentrated more narrowly on waiting time, voyage execution and virtual arrival (Appendix 1).

In order to cover the diversity of ship types, sizes and trading patterns, interviewees were drawn from companies with vessels ranging from 3,000 dwt to 300,000 dwt, and engaged in both short-sea and longhaul trades (Table 1). Ships employed in short-sea trades, call at ports frequently and spend proportionally more time alongside (i.e. in port or on a jetty) than ships in long-haul trades. Consequently, virtual arrival and reduced port time would be expected to have the highest impact on fuel consumption/GHG emissions in short-sea trades.

In 2012-13 tanker and dry bulk shipping personnel were interviewed. However dry bulk interviewees argued that the tanker trades were more advanced with regard to use of virtual arrival (Interviewees 4,5, 8, 12 and 16, please see Table 1) and so in 2018 we focused our attention on this sector.

We recorded and transcribed all face to face interviews and coded them with two email interviews using qualitative text software (NVivo). Where interviews were conducted in Scandinavian languages we translated quotes into English.

\subsection{Ethnographic onboard studies}

To supplement our interviews with shore-based operational staff we drew upon ethnographic material collected while sailing onboard two tankers (Please see Table 2 for details on the voyages). One voyage was undertaken specifically in relation to this study whilst the other was conducted in conjunction with research on ship-shore interaction and the use of mandatory equipment and contained material which was highly relevant to this research.

In relation to the voyage which was tailored to this study NN [anonymized for peer review] set out to identify the crew's different tasks in ship operations and voyage execution. He was particularly interested in the factors which affect the timing and duration of each task and he documented the different tasks, and activities, which took place during the different phases of the ship's voyage. In terms of the second voyage NN [anonymized for peer review] was particularly concerned with daily work and life on board and paid particular attention to interaction between seafarers and all port personnel. In the course of this voyage data emerged which shed strong light on some of the issues pertaining to virtual arrival. The emergence of such data was a feature of the grounded research design and wholly compatible with the research design.

PLEASE ADD TABLE 2 HERE 


\section{Table 2. Overview of our onboard studies}

\subsection{Content analysis}

We undertook a content analysis of 'grey literature; to contextualize, confirm, or disconfirm, our interview data and observations. All articles in the global shipping newspaper Lloyd's List, published after 1990, which contained the words "virtual arrival" or "contango" (which is the deliberate use of tankers for floating storage in anticipation of oil price increases) were analyzed to consider the extent to which they supported or confounded our findings.

\section{Analysis}

\subsection{Port and terminal logistical challenges}

Timely arrival in port is critical to the maximization of ship-operator earnings according to our interviewees. A head of chartering in a tanker shipping company explained the incentives for punctual arrival:

...if our laydays, or our time window [for arrival to the port] is between July $1^{\text {st }}$ and $3^{\text {rd }}$, it is in our own interest to arrive as early as possible. Not June 25 ... that's not in our interest, but not on July $5^{\text {th }}$ either. In that case, they [the charterer] will kick us out. So we have to arrive within the window. ... If we arrive on July $1^{\text {st }}$ and tender notice of readiness at 00.01 , then our time counting is most effective... (Interviewee 21).

Upon arrival, the captain tenders a notice of readiness to the charterer to indicate that the ship is ready for loading or discharging. The interviewees confirm that the notice of readiness is an important legal document, which signals contractual compliance and impacts on earnings.

Our onboard observations also confirmed that the timing of tendering of the notice of readiness was important to the master, one of whom explained to us that he will tender it to the shipping company, the broker, the terminal, the charterer and the agent. On the bridge the ECDIS-system constantly displayed the Expected Time of Arrival to port (ETA), and the master explained:

The arrival time has implications for voyage revenue, and the shipping company does not want the ship to arrive too early... The lay-can, which is the agreed time period for the tendering of notice of readiness in accordance with the charter party, is important to observe. If the vessel arrives late, the shipping company will be in trouble. If the vessel arrives early at the jetty, the charterer will have to pay extra port charges. For the master it important to arrive on time as advised by the shipping company operations' manager (Fieldnotes from Northern Hemisphere).

Thus it would appear that ship operators actively seek to arrive in port and to wait. When asked, if waiting time occurs, a vice president of tanker operations replied:

A lot. I would say. But it is also very seasonal and in different ports. ... We can probably look at the exact statistics but in around $75 \%$ of the voyages we perform there is demurrage...[...] And then half of those is almost always at anchorage that waiting time occurs. So we probably wait, yeah, $80 \%$ of the cases ... or $70 \%$ (Interviewee 29 ). 
However, deliberate orchestration of arrival time is not the only reason why ships wait at anchor and congestion may produce additional delays. Interviewees explained that waiting time varies between ports. In 2012-13 dry bulk interviewees singled out Brazilian and Australian ports as major points of congestion and long waiting times (Interviewees 4, 6, and 11). Interviewees mentioned examples of 30-80 day waits (Interviewees 4, 6, and 11). Such delays are in line with the operational interests of vessel operators and in 2013, a dry bulk ship-owner explained that:

The ship-owner doesn't care, because he gets paid. He receives waiting money [demurrage]. .... Down in South America, current waiting times are 70-80 days. We are very happy about that (Interviewee 6).

At anchor, the crew turn off the main engines, and auxiliary engines provide power for hotel functions, cargo-heating etc. If the weather does not permit anchoring, the vessel will drift slowly in a safe area, which both authors experienced in the course of their voyages. This is the less preferable option and a head of chartering explained that:

We will do whatever we can to anchor. Then we don't need to drift. When drifting, we will use an additional 3 to 4 tons of bunkers per day to keep the ship running (Interviewee 24).

Both chartering and operations managers saw waiting times as attractive for two reasons. Waiting withdraws capacity from the freight market (Interviewees 4, and 6) and at the same time ship-owners earn demurrage. Demurrage is important revenue for ship-owners, particularly with depressed freight markets. In an interview in 2018, a senior operations manager explained that the shipping company earnt its profit while waiting at anchor. In April 2018, the daily time charter equivalent (TCE) for a handy size tanker was around USD 12,000, but demurrage was USD 18,000 per day (Interviewee 19). The head of operations acknowledged that their ships, operating in the spot market, consumed extra fuel while sailing, but demurrage outweighed the extra fuel costs.

All our interviewees attributed some port waiting time to terminal logistical challenges. Sometimes berths were occupied by previously delayed vessels. In other cases refineries did not have available cargo. In cases of discharging, lack of tank storage capacity also caused delayed berthing. Interviewees explained that such situations are entirely beyond their control but that they were not unhappy with them. As a vice president of tanker chartering explained:

[...] We cannot influence the operation... In fact, it is an advantage to us, if they [the charterer and oil terminal] make mistakes, so that the whole process will take longer (Interviewee 21).

\subsection{Cargo values and fuel savings}

In this context, it is understandable that ship operators may not be highly incentivized to push for virtual arrival clauses in their charter parties nevertheless they argued that they were ready to offer it to their charterers, but it was not requested (Interviewees $2,3,11,16$, and 18). The head of sustainability in a shipping company explained: 
All documents and everything are ready [for virtual arrival]. Many customers decline the offer, however. Unfortunately. So it is not the great success we had dreamt of (Interviewee 16).

An operator of dry bulk vessels referred to cargo-owner preferences for fast delivery and port first-comefirst-serve policies. He said:

But with regard to virtual arrival. We have discussed it with several of the large costumers. They just reply: Forget it. It makes no sense. They see no reason to use it. The only thing that matters for them is to get the ship to port, which then decides when the ship can dock (Interviewee 5).

In 2018, little had changed in this regard. Virtual arrival was not widely adopted (Interviewees 21, and 24). The absence of virtual arrival was also evidenced by articles in Lloyd's List, which had published only one article with a mention of "virtual arrival" since September 2014 (on January 12, 2016). In 2019, Lloyd's List quoted an IMO representative for the following:

Ships spend a lot of time waiting to enter ports... On average, a ship might spend $5 \%-10 \%$ of a voyage waiting at an anchorage (Lloyds' List 2019).

Several interviewees argued that charterers were driven by commercial priorities relating to markets for valuable cargo (Interviewees 4, 16, 17, and 24). Cargo values significantly outweigh freight bills and fuel costs. Oil prices are highly volatile, and this volatility provides the basis for trading and speculation for commodity traders on the world's commodity exchanges. Cargoes are traded while onboard and can change owners several times during transit. Moreover, the discharging port can change several times during a voyage. Both a head of chartering (Interviewee 24) and a senior officer, with whom we talked to onboard, attested to this. Our fieldnotes from our conversation with the senior officer stated the following:

Over lunch, we discussed the destination port for the vessel. The senior officer explained that the destination is not always known [even after departure], and recalled a voyage from Algeciras [at the Gibraltar Straits] into the Atlantic Basin. The crew did not know where the ship was going. Six different ports - from New York in the north to Houston in the south were on the table, while the ship was en route. He explained that the vessel steered "a middle course", until the crew received instructions about which port, the cargo had been sold to. ... The oil price and the differences in oil prices between ports determine the destination of the ship (Fieldnotes from Northern Hemisphere).

Even though such navigation means higher fuel consumption, charterers exhibit commercially rational behavior. To them the value of the cargo is a more important variable than fuel cost.

To explore the explanation with another data set, we have investigated the Bro Elizabeth virtual arrival case, described in Section 1. As disclosed by BP and Maersk, virtual arrival enabled BP to reduce the freight bill by USD 12,400 from 539,400 to 527,000 due to fuel savings (Table 4). If - for the sake of illustration we assume that the tanker was fully loaded with 37,000 tonnes of crude oil and that the price per barrel increased from USD 50 to 52 during the voyage (by four per cent), the cargo value would have appreciated by over USD 0.54 million from USD 13.60 million to USD 14.15 million (Table 5). This is a conservative 
estimate of oil price changes. In 2009, crude oil prices fluctuated between 35 and 80 USD per barrel. Even a small percentage increase in cargo value would indeed significantly offset fuel savings from virtual arrival.

This explanation is also supported by evidence in the shipping press. In market reports in Lloyd's List, there are numerous mentions of fully loaded tankers, which have anchored for days, weeks or even months, while waiting for berthing instructions from charterers. If the charterer expects oil prices to rise, he or she may be willing to wait and pay demurrage. The situation when numerous tankers are used for floating storage, as commodity traders speculate and wait for rising oil prices, is called contango (Lloyd 's List 2015a, 2015b). Waiting time at anchorage is a commercially rational decision for the charterer, given the demurrage rate and the cargo value. The potential gains from an appreciation in cargo value will outweigh the potential benefits associated with virtual arrival.

These were not the only disincentives to charterers with regard to virtual arrival agreements. There were also financial risks attached to potential delays resulting from unforeseen events making charterers reluctant to cut things too fine in relation to timing. A ship operator explained that:

That it is a risk of not having the ship in port as well. Because if refining has to close down or whatever, that would cost so much more than that what you can potentially save by having a ship arrive one day later. We also have gas tankers ... and there we see they [charterers] want the ships to be in port even though they are there 3 or 4 days early. Then they'll rather see the ship steaming full ahead, just to be there in port and then steaming around for 3 or 4 days, until they will go in just to make sure (Interviewee 29).

The explanations we received from the shipping company interviewees during the two interview rounds were very similar. According to the ship-owner interviewees, the charterers are more concerned about certainty for delivery of a highly valuable cargo than any possible fuel savings from virtual arrival. Several interviewees explained that the costs of an oil terminal or refinery closure due to a vessel, which has only arrived virtually, but not physically, greatly exceed the benefits of bunker savings (Interviewees 3, 10, 16, and 18). A fuel efficiency manager in a tanker shipping company technical organization stated:

They [the refineries] like to have ships waiting, because it is a really bad thing not to have any oil to process. You don't want to stop a refinery, so it needs to keep moving, so if there is a delay, it is nice to have somebody standby, who can come in...(Interviewee 18 ).

\subsection{Lack of trust}

Some of our shipping interviewees - both in 2012-13 and 2018 - added one further explanation to the absence of virtual arrival in shipping: lack of trust between the shipping companies and the ports. They argued that in many ports a ship would run the risk of "losing its ticket in the waiting line for berth", if they only arrived virtually (Interviewees 5 and 16). A gas tanker shipping company CEO emphasized lack of trust, when explaining why cargo-owners rejected offers to include a virtual arrival clause in charter parties.

Virtual arrival clauses? We also have that. It's not widely accepted in the gas tanker industry. Yes, but, eh, the theory is good. Practice is difficult. ... It's because of trust. I don't think many terminals have trust. ... In some parts of the world, trust comes in very short supply. If you 
call them and say: I should have arrived $1700 \mathrm{hrs,} \mathrm{but} \mathrm{I} \mathrm{will} \mathrm{only} \mathrm{arrive} \mathrm{at} 2300 \mathrm{hrs}$, they will just say, okay, then your arrival time is $2300 \mathrm{hrs}$. (Interviewee 27 ).

Finally, some interviewees also added that the validation of fuel savings from virtual arrival remains a difficult issue. Despite the use of a third party weather service provider, they found difficulties in verifying the fuel savings achieved vis-à-vis charterers (Interviewees 1, 5, 18 and 24). These factors may also prevent the implementation of virtual arrival.

\subsection{Unintended consequences of virtual arrival}

In our conversations with seafarers onboard, they explained how vessel trading patterns affect their stress levels. A bridge officer:

...was really tired of the frequent port calls, which are very stressful. He was hoping for a long voyage soon, for instance a voyage of 17 days duration to Nigeria (Quoted from fieldnotes, Northern Hemisphere)

Another senior officer explained that:

...he had had to work until 2 am with administrative tasks. There is simply so much administrative work to do before a port call... This is particularly stressful in connection with frequent port calls and short voyages.

He explained that administrative procedures differed from port to port, adding further burdens. He would recommend to the shipping company only to send young senior officers onboard ships in the short-sea trades. Stress levels were very high due to very high administrative burdens and frequent disruptions of sleep (Fieldnotes from Northern Hemisphere).

Seafarers unanimously described how short-sea trades are stressful as a result of very frequent port calls, and this is consistent with our own observations. In short sea trades, many voyages take place in fairways with dense traffic and pilots are often onboard, adding to demands on seafarers. Sleep patterns are also subject to considerable disruption as port calls and associated pilot/tug operations, visits from officials and inspectors, may take place at any time day/night. As a result in short-sea trades many seafarers see time at anchorage as a welcome opportunity to catch up on work and/or rest. As an officer at anchor explained: "This is simply the best time for me" (Quoted from our fieldnotes, Northern Hemisphere).

A technical superintendent with seafaring experience explained the main differences between the working environment and working pace onboard vessels employed in the long-haul and short-haul trades as follows:

The major difference is stress. Many people simply cannot cope, working on small ships [employed in short trades]. They need ships in long-haul trades. Where they have much more time for different things.[...] On the small ships, on the short hauls, [...] You are always behind with your work. There are always things to do. And then you have all the stuff that can suddenly appear. In a matter of minutes. And that causes stress. That you don't control your own day (Interviewee 25). 
Other shipping company interviewees with small vessels employed in short-haul trades supported this account (Interviewees 28, and 30).

In this context it is important to bear in mind that reduced waiting time may have unintended negative consequences in adding to seafarer fatigue. This is an important factor to take into consideration, when assessing the energy efficiency potential in voyage execution.

\section{Discussion}

$20^{\text {th }}$ century maritime history provides several examples of successful efficiency measures in the shipping industry. Most notably, the container revolution and improved cargo-handling methods enabled liner ships to radically reduce time in port in the 1960s and 1970s thereby increasing revenue earning potential (Poulsen et al. 2007). Today the quest for efficiency in the intensely competitive shipping industry continues. Several recent studies (Johnson and Styhre 2015; Jia et al. 2017; Andersson and Ivehammar 2017) and prominent ship-owner associations (BIMCO and Intertanko) have pointed to the potential for reduced waiting times for tankers and dry bulk ships at berth/anchorage. Relying on satellite data, Jia et al. (2017) and Andersson and Ivehammar (2017) showed that waiting at anchor is common, in particular for tankers.

Notwithstanding the inherent incentives for the reduction of waiting time our study confirms the widespread occurrence of waiting time at anchor and the very limited uptake of virtual arrival. However it goes beyond this, developing more nuanced explanations for rapid transit and associated waiting time than have been available hitherto. We show that cargo-owners have commercial imperatives other than fuel savings. Waiting time at anchor is not the result of irrational behavior in shipping. On the contrary, waiting time occurs because of the commercial imperatives of cargo-owners, for whom access to highly valuable cargoes is more important than fuel savings. Our findings are consistent with the study on cargo-owner greening of shipping by Poulsen et al. (2016). It demonstrated that tanker shipping cargo-owners are not especially concerned with air emission abatement in shipping, but restrict their attention towards oil spill prevention.

Jia et al. (2017) have proposed that the IMO and EU should consider policy measures aimed at compelling operators to implement virtual arrival in shipping. Our findings suggest, however, that the commercial benefits (for cargo-owners) of quick access to cargo considerably outweigh the benefits of fuel savings by several orders of magnitude. In this context, it is unlikely that policy measures, such as a global tax on bunkers or an emission trading scheme, would be sufficient to eliminate such practices.

We have identified the fact that whilst many of the factors militating against the uptake of virtual arrival are beyond the control of shipping companies they nevertheless benefit from rapid transit to ports followed by prolonged waits. Given these dynamics our study suggests that shipping is unlikely to realize the potential for GHG abatement via virtual arrival as suggested by Jia. et al. (2017), Andersson and Ivehammer (2017) and Johnson and Styhre (2015).

In 1998, Shove et al. argued that studies on energy efficiency often identify a technical potential for energy efficiency, but fail to understand the social practices that make its achievement difficult or impossible. The studies by Jia et al. (2017), Andersson and Ivehammer (2017) and Johnson and Styhre (2015) identified a significant potential for energy efficiency through virtual arrival, but our study provides a more nuanced 
understanding of this potential leading us to conclude that as a result of charterers' commercial priorities, shipping is unlikely to achieve this potential.

Importantly, our study also highlights the risks of unintended negative consequences associated with virtual arrival. The risks of seafarer fatigue, in particular, are important to consider. Pauksztat (2017) has shown that seafarer fatigue is associated with particular trading patterns and schedules, concluding that "...Higher number of port calls (and to some extent lower numbers of days at sea) also increase fatigue levels." (Pauksztat 2017, p. 623). These conclusions are consistent with our analysis.

Finally, we make a methodological contribution to transportation research on climate change mitigation, which has tended to adopt quantitative and positivist approaches (Schwanen et al. 2011). We show how a combination of qualitative methods - semi-structured interviews and non-participant observation - can advance our knowledge of phenomena (such as the apparent inefficiencies of waiting time in a highly competitive industry), which have puzzled the predominantly quantitative transportation research for long. In this regard, our work aligns with the recent call by Schwanen et al. (2011) for methodological plurality within transportation research. Our study also resonates well with the ethnographic methods recently employed by Viktorelius and Lund (2019) in their onboard study on energy efficiency in ferry shipping.

\section{Conclusion}

A reduction of waiting time for ships in port/at anchor has been proposed both by researchers, and prominent ship-owner associations, as a means of realizing the IMO's goals for the abatement of greenhouse gas emissions. In theory the implementation of virtual arrival could allow ships to slow down en route and save fuel/reduce air emissions without reducing capacity or extending transportation time overall - to the benefit of both businesses and environment. In practice however charterers' commercial considerations outweigh the benefits from virtual arrival. Most cargoes exhibit significant price volatility and their values exceed the costs of freight and bunkers by many orders of magnitude. Virtual arrival does not appeal to most charterers, who are more focused on ensuring immediate access to highly valuable cargoes. From the point of view of the charterers (oil majors or commodity traders), it may be perfectly rational for a fully loaded ship to sit idle at anchorage, even though this increases fuel costs and requires demurrage payments to ship-owners. By being in the right spot at the right time charterers enhance their chances of selling the cargo at an attractive price. By the same token it is also advantageous for ship companies to have their vessels wait at anchor earning demurrage. This allows them to increase profit margins, catch up on maintenance, and allow seafarers to catch up on much-needed rest.

In developing transportation research on air emission abatement and energy efficiency further it would be beneficial to explore the alternatives to virtual arrival with different types of charterers, such as oil majors, commodity traders, mines and agro-businesses. Future studies could investigate under which circumstances different types of charterers - both in tanker and dry bulk shipping - might be willing to include/exercise virtual arrival in charter parties or what alternatives might be considered instead. It would also be relevant to explore the lack of trust among stakeholders in ship operations, and the question of how to improve trust to abate air emissions.

Our findings have implications for the achievement of the IMO's GHG goals. Unfortunately, despite their early promises virtual arrival agreements appear unlikely to make a significant contribution to the 
achievement of these goals. Shipping is unlikely to achieve the potential for GHG abatement via these particular energy efficiency measures that several studies have previously identified as so promising. Our study shows how cargo-owners' commercial priorities and decisions have a significant effect on air emissions from shipping, and indicates that the IMO should consider involving them more directly in their efforts to abate emissions from shipping. Our research suggests that policy makers urgently need to broaden their focus and consider a greater range of measures to ensure that they meet the required emissions reductions agreed at IMO.

\section{Acknowledgements}

We would like to express our gratitude to the two shipping companies, which enabled us to carry out studies onboard their tankers.

Our research was generously supported by the The Danish Maritime Fund, the Canadian Social Sciences and Humanities Research Council, Lloyd's Register Foundation*, The TK Foundation, Cardiff University and Copenhagen Business School. We would like to express our gratitude for this.

We would also like to thank Siri Pettersen Strandenes, Liping Jiang, Michele Acciaro and Nishatabbas Rehmatulla for their valuable comments to an earlier version of our article.

*Lloyd's Register Foundation helps to protect life and property by supporting engineering-related education, public engagement and the application of research.

\section{References}

Adland, R., Cariou, P., Jia, H., \& Wolff, F. C. (2018). The energy efficiency effects of periodic ship hull cleaning. Journal of Cleaner Production, 178, 1-13.

Andersson, P., \& Ivehammar, P. (2017). Green approaches at sea: The benefits of adjusting speed instead of anchoring. Transportation Research Part D: Transport and Environment, 51, 240-249.

Bazari, Z., Longva, T., 2011. Assessment of IMO mandated energy efficiency measures for international shipping. International Maritime Organization, London, UK.

BIMCO (2011). Slow Steaming Clause for Time Charter Parties, BIMCO Special Circular No. 7, December 23, Bagsvaerd: BIMCO.

BIMCO (2013). Virtual Arrival Clause for Voyage Charter Parties, BIMCO Special Circular no. 9, October 4, Bagsvaerd: BIMCO.

Bows-Larkin, A. (2015). All adrift: aviation, shipping, and climate change policy. Climate Policy, 15.6: 681702.

BP/Maersk (2010). Virtual Arrival. BP Shipping and Maersk Tankers, https://weathernews.com/TFMS/topics/seminar/2010/pdf/4 BP Maersk.pdf, accessed on July 6, 2018.

BP (2011). A new wave of efficiency, BP Magazine, Issue 2, 42-45. 
Brynolf, S., Fridell, E., \& Andersson, K. (2014). Environmental assessment of marine fuels: liquefied natural gas, liquefied biogas, methanol and bio-methanol. Journal of Cleaner Production, 74, 86-95.

Cariou, P. (2011). Is slow steaming a sustainable means of reducing CO2 emissions from container shipping?. Transportation Research Part D: Transport and Environment, 16(3), 260-264.

Chang, C.-C., \& Wang, C.-M. (2014). Evaluating the effects of speed reduce for shipping costs and CO2 emission, Transportation Research Part D, 31, 110-115.

Chung, Y. S., Lee, P. T. W., \& Lee, J. K. (2017). Burnout in seafarers: its antecedents and effects on incidents at sea. Maritime Policy \& Management, 44(7), 916-931.

Corbett, J. J., Wang, H., \& Winebrake, J. J. (2009). The effectiveness and costs of speed reductions on emissions from international shipping. Transportation Research Part D: Transport and Environment, 14(8), 593-598.

Du, Y., Chen, Q., Quan, X., Long, L., \& Fung, R. Y. (2011). Berth allocation considering fuel consumption and vessel emissions. Transportation Research Part E: Logistics and Transportation Review, 47(6), 1021-1037.

Eide, M.S., Longva, T., Hoffmann, P., Endresen $\varnothing$. \& Dalsøren, S.B. (2011): Future cost scenarios for reduction of ship $\mathrm{CO} 2$ emissions, Maritime Policy \& Management, 38(1), 11-37

Faber, J., Wang, H., Nelissen, D., Russell, B., \& Amand, D. (2011). Marginal abatement costs and cost effectiveness of energy-efficiency measures. IMO MEPC 62 INF 7, The Society of Naval Architects and Marine Engineers (SNAME)/IMO: London.

Fagerholt, K., Laporte, G., \& Norstad, I. (2010). Reducing fuel emissions by optimizing speed on shipping routes. Journal of the Operational Research Society, 61(3), 523-529.

Gibbs, D., Rigot-Muller, P., Mangan, J., \& Lalwani, C. (2014). The role of sea ports in end-to-end maritime transport chain emissions. Energy Policy, 64, 337-348.

Golias, M. M., Saharidis, G. K., Boile, M., Theofanis, S., \& lerapetritou, M. G. (2009). The berth allocation problem: Optimizing vessel arrival time. Maritime Economics \& Logistics, 11(4), 358-377.

IMO (2009). Guidance for the development of a ship energy efficiency management plan (SEEMP), MEPC.1/Circ.683. London: IMO

IMO (2016). IMO Train the Trainer (TTT) Course on Energy Efficient Ship operations: Module 3 from Management to Operation. London: IMO.

IMO (2018). Adoption of the Initial IMO Strategy on Reduction of GHG Emissions from Ships and Existing IMO Activity Related to Reducing GHG Emissions in the Shipping Sector, Note by the International Maritime Organization to the UNFCCC Talanoa Dialogue, April 13, London: IMO.

Intertanko/OCIMF (2010). Virtual arrival: Optimising Voyage Management and Reducing Vessel Emissions An Emissions Management Framework. First Edition, London: Intertanko/Oil Companies International Marine Forum. 
Intertanko (2011). Launch of Virtual Arrival in presence of EU Commissioner for Transport, Press release, June 24 , Intertanko.

Jia, H., Adland, R., Prakash, V., \& Smith, T. (2017). Energy efficiency with the application of Virtual Arrival policy. Transportation Research Part D: Transport and Environment, 54, 50-60.

Johnson, H., Johansson, M., Andersson, K., \& Södahl, B. (2013). Will the ship energy efficiency management plan reduce $\mathrm{CO} 2$ emissions? A comparison with ISO 50001 and the ISM code. Maritime Policy \& Management, 40 (2), 177-190.

Johnson, H., Johansson, M., \& Andersson, K. (2014). Barriers to improving energy efficiency in short sea shipping: an action research case study. Journal of Cleaner Production, 66, 317-327.

Johnson, H., \& Styhre, L. (2015). Increased energy efficiency in short sea shipping through decreased time in port. Transportation Research Part A: Policy and Practice, 71, 167-178.

Knorring, H. v. (2019). Energy audits in shipping companies, Transportation Research Part A: Policy and Practice, 125, 35-55.

Kristiansen, S. \& Krogstrup, H.K. (1999). Deltagende observation. Copenhagen: Hans Reitzel's Forlag

Kvale, S., \& Brinkmann, S. (2009). Interviews: Learning the Craft of Qualitative Research Interviewing. Second edition, Los Angeles and London: Sage.

Lalla-Ruiz, E., Shi, X., \& Voss S. (2018). The waterway ship scheduling problem. Transportation Research Part $D, 60,191-209$.

Lindstad, H., Asbjørnslett, B. E., \& Strømman, A. H. (2011). Reductions in greenhouse gas emissions and cost by shipping at lower speeds. Energy Policy, 39(6), 3456-3464.

Lister, J., Poulsen, R. T., \& Ponte, S. (2015). Orchestrating transnational environmental governance in maritime shipping. Global Environmental Change, 34, 185-195.

Lloyd's List (2009). Slow steaming to benefit all, Lloyd's List, December 1.

Lloyd's List (2010). Tanker sector eyes savings potential from a timely arrival. Lloyd's List, November 16.

Lloyd's List (2011a). Share the savings to drive down emissions, Lloyd's List, April 7.

Lloyd's List (2011b). A step by step guide to the Virtual Arrival process, Lloyd's List, July 6.

Lloyd's List (2015a). Floating crude storage set to ignite already booming VLCC demand, Lloyd's List, January 7.

Lloyd's List (2015b). VLCC storage play begins in earnest, Lloyd's List, January 13

Lloyd's List (2016). Getting it together, Lloyd's List, January 12.

Lloyd's List (2018). MSC close to finalising five-year ship refit programme, Lloyd's List, February 12. 
Lloyd's List (2019). 'Smarter' ports can help cut emissions, Lloyd's List, February 19.

Maersk (2009). Sustainability Report 2009. A.P. Moller-Maersk, Copenhagen.

Mander, S. (2017). Slow steaming and a new dawn for wind propulsion: A multi-level analysis of two low carbon shipping transitions. Marine Policy, 75, 210-216.

Mokia, Z \& Dinwoodie, J (2002). Spatial aspects of tanker lay-times, Journal of Transport Geography, vol 10, $39-49$

Panayides, P.M. Principles of Chartering, $3^{\text {rd }}$ edition. CreateSpace Publishing: North Charleston, SC, USA.

Pauksztat, B. (2017). Effects of job demands and social interactions on fatigue in short sea cargo shipping. Maritime Policy \& Management, 44(5), 623-640.

Pettit, S., Wells, P., Haider, J. and Abouarghoub, W. (2018). Revisiting history: Can shipping achieve a second socio-technical transition for carbon emissions reduction?, Transportation Research Part D: Transport and Environment, 58, 292-307.

Poulsen, R.T. (2007). Liner Shipping and Technological Innovation: Ostasiat and the Container Revolution, 1963-75. Scandinavian Economic History Review, 55(2), 83-100.

Poulsen, R. T., \& Johnson, H. (2016). The logic of business vs. the logic of energy management practice: understanding the choices and effects of energy consumption monitoring systems in shipping companies. Journal of Cleaner Production, 112, 3785-3797.

Poulsen, R. T., Ponte, S. \& Lister, J. (2016). Buyer-driven greening? Cargo-owners and environmental upgrading in maritime shipping, Geoforum, 68 (January), 57-68,

Poulsen, R. T., Ponte, S., \& Sornn-Friese, H. (2018). Environmental upgrading in global value chains: The potential and limitations of ports in the greening of maritime transport. Geoforum, 89, 83-95.

Poulsen, R. T., \& Sornn-Friese, H. (2015). Achieving energy efficient ship operations under third party management: How do ship management models influence energy efficiency?. Research in Transportation Business \& Management, 17, 41-52.

Psaraftis, H.N. (2018). Decarbonisation of maritime transport: to be or not to be? Maritime Economics and Logistics, 1-19.

Psaraftis, H.N. (2019). Speed Optimization vs Speed Reduction: the Choice between Speed Limits and a Bunker Levy, Sustainability 11(8), 2249.

Qi, X., \& Song, D. P. (2012). Minimizing fuel emissions by optimizing vessel schedules in liner shipping with uncertain port times. Transportation Research Part E: Logistics and Transportation Review, 48(4), 863-880.

Rehmatulla, N. (2014). Market failures and barriers affecting energy efficient operations in shipping, London: University College London. 
Rehmatulla, N., \& Smith, T. (2015). Barriers to energy efficiency in shipping: A triangulated approach to investigate the principal agent problem. Energy Policy, 84, 44-57.

Rojon, l., \& Dieperink, C. (2014). Blowin'in the wind? Drivers and barriers for the uptake of wind propulsion in international shipping. Energy Policy, 67, 394-402.

Sampson, H. (2013). International seafarers and transnationalism in the twenty-first century. Manchester University Press.

Schwanen, T., Banister, D., \& Anable, J. (2011). Scientific research about climate change mitigation in transport: A critical review. Transportation Research Part A: Policy and Practice, 45(10), 993-1006.

Shove, E. (1998). Gaps, barriers and conceptual chasms: theories of technology transfer and energy in buildings. Energy Policy, 26(15), 1105-1112.

Smith, T.W.P., Jalkanen, J.P., Anderson, B.A., Corbett, J.J., Faber, J., Hanayama, S., O'keeffe, E., Parker, S., Johansson, L., Aldous, L., Raucci, C., Traut, M., Ettinger, S., Nelissen, D., Lee, D.S., Ng, S., Agrawal, A., Winebrake, J.J., Hoen, M., Chesworth, S., \& Pandey, A. (2014). Third IMO GHG Study 2014. International Maritime Organization (IMO), London, UK.

Stopford, M. (2009). Maritime Economics, $3^{\text {rd }}$ edition, Routledge.

Styhre, L., Winnes, H., Black, J., Lee, J., \& Le-Griffin, H. (2017). Greenhouse gas emissions from ships in ports-Case studies in four continents. Transportation Research Part D: Transport and Environment, 54, 212224.

UNCTAD (2018). Review of Maritime Transport 2018. Geneva: UNCTAD.

Viktorelius, M., \& Lundh, M. (2019). Energy efficiency at sea: An activity theoretical perspective on operational energy efficiency in maritime transport. Energy Research \& Social Science (52), 1-9.

Wang, K., Yan, X., Yuan, Y., Jiang, X., Lin, X., \& Negenborn, R. R. (2018). Dynamic optimization of ship energy efficiency considering time-varying environmental factors. Transportation Research Part $D$ : Transport and Environment, 62, 685-698.

Zis, T., North, R. J., Angeloudis, P., Ochieng, W. Y., \& Bell, M. G. H. (2014). Evaluation of cold ironing and speed reduction policies to reduce ship emissions near and at ports. Maritime Economics \& Logistics, 16, 371-398.

\section{Table 1. Interviewees}

\begin{tabular}{|r|l|l|l|l|l|}
\hline $\begin{array}{l}\text { Inter- } \\
\text { viewee } \\
\text { no. }\end{array}$ & $\begin{array}{l}\text { Inter- } \\
\text { view } \\
\text { no. }\end{array}$ & Position & Shipping segment(s) & Date & $\begin{array}{l}\text { Duration of } \\
\text { interview }\end{array}$ \\
\hline 1 & 1 & $\begin{array}{l}\text { Senior manager, Technical } \\
\text { department }\end{array}$ & Product tankers & August 21, 2012 & $01: 05: 22$ \\
\hline 2 & 2 & CEO & Product tankers & August 24, 2012 & 01:17:59 \\
\hline
\end{tabular}




\begin{tabular}{|c|c|c|c|c|c|}
\hline 3 & 2 & $\begin{array}{l}\text { Senior manager, Technical } \\
\text { department }\end{array}$ & Product tankers & August 24, 2012 & 01:17:59 \\
\hline 4 & 3 & Managing Director & Dry bulk & Nov. 29, 2012 & 01:37:57 \\
\hline 5 & 4 & $\begin{array}{l}\text { Senior Manager, Chartering } \\
\text { department }\end{array}$ & Dry bulk & April 17, 2013 & 01:18:16 \\
\hline 6 & 5 & Managing Director & Dry bulk & May 7, 2013 & 01:16:30 \\
\hline 7 & 6 & $\begin{array}{l}\text { General Manager, } \\
\text { Chartering department }\end{array}$ & Dry bulk & May 8, 2013 & $02: 20: 40$ \\
\hline 8 & 6 & $\begin{array}{l}\text { Senior Vice President, } \\
\text { Operations department }\end{array}$ & Dry bulk & May 8, 2013 & 02:20:40 \\
\hline 9 & 6 & Chief Technical Officer & Gas & May 8, 2013 & $02: 20: 40$ \\
\hline 10 & 7 & Executive Vice President & Product tankers & May 3,2013 & 01:13:53 \\
\hline 11 & 8 & $\begin{array}{l}\text { Senior Vice President, } \\
\text { Operations department }\end{array}$ & Dry bulk & May 6, 2013 & 01:40:19 \\
\hline 12 & 9 & $\begin{array}{l}\text { Head of technical } \\
\text { department }\end{array}$ & Dry bulk & May 6, 2013 & 01:29:23 \\
\hline 13 & 10 & Director, Chartering & Product tankers & May 16, 2013 & $01: 46: 37$ \\
\hline 14 & 10 & $\begin{array}{l}\text { Director, Technical } \\
\text { department }\end{array}$ & Product tankers & May 16, 2013 & 01:46:37 \\
\hline 15 & 10 & Executive Vice President & Product tankers & May 16, 2013 & 01:46:37 \\
\hline 16 & 11 & Director, CSR & Tankers and dry bulk & June 19, 2013 & 01:41:21 \\
\hline 17 & 11 & $\begin{array}{l}\text { Director, Technical } \\
\text { department }\end{array}$ & Tankers and dry bulk & June 19, 2013 & 01:41:21 \\
\hline 18 & 12 & $\begin{array}{l}\text { Fuel Optimization Manager, } \\
\text { Technical Organization }\end{array}$ & $\begin{array}{l}\text { Product, crude oil and } \\
\text { gas tankers }\end{array}$ & June 27, 2013 & 01:33:19 \\
\hline 19 & 13 & $\begin{array}{l}\text { Senior manager, Operations } \\
\text { department }\end{array}$ & Product tankers & April 17, 2018 & $\begin{array}{l}\text { Telephone } \\
\text { interview, not } \\
\text { transcribed }\end{array}$ \\
\hline 20 & 14 & $\begin{array}{l}\text { Executive vice president, } \\
\text { Technical department }\end{array}$ & Product tankers & March 24, 2018 & $\begin{array}{l}\text { E-mail } \\
\text { correspondence }\end{array}$ \\
\hline 21 & 13 & $\begin{array}{l}\text { Vice president, chartering } \\
\text { department }\end{array}$ & Chemicals & June 26, 2018 & 01:18:59 \\
\hline 22 & 13 & $\begin{array}{l}\text { Vice president, technical } \\
\text { department }\end{array}$ & Chemicals & June 26, 2018 & 01:18:59 \\
\hline 23 & 14 & $\begin{array}{l}\text { Head of Projects, technical } \\
\text { department }\end{array}$ & LPG & July 4, 2018 & 01:23:14 \\
\hline 24 & 15 & Head of chartering & Product & July 10, 2018 & 01:02:49 \\
\hline 25 & 15 & $\begin{array}{l}\text { Vice president, technical } \\
\text { department }\end{array}$ & Product & July 10, 2018 & 01:02:49 \\
\hline 26 & 16 & Technical superintendent & Chemicals and product & July 18, 2018 & $00: 55: 24$ \\
\hline 27 & 17 & CEO & Gas & July 24, 2018 & 00:53:41 \\
\hline 28 & 18 & Chief Operating Manager & Chemicals & August 20, 2018 & 01:09:40 \\
\hline 29 & 19 & $\begin{array}{l}\text { Vice President, Operations } \\
\text { department }\end{array}$ & $\begin{array}{l}\text { LNG, chemicals and } \\
\text { product }\end{array}$ & August 21, 2018 & $00: 52: 56$ \\
\hline 30 & 20 & $\begin{array}{l}\text { General Manager, } \\
\text { Chartering department }\end{array}$ & Chemicals and product & August 29, 2018 & 00:53:09 \\
\hline
\end{tabular}


Table 2. Overview of our onboard studies

\begin{tabular}{|l|l|l|l|l|l|l|}
\hline Ship type & $\begin{array}{l}\text { Number of } \\
\text { port calls }\end{array}$ & $\begin{array}{l}\text { Number of } \\
\text { voyages }\end{array}$ & Itinerary & $\begin{array}{l}\text { Number of } \\
\text { days onboard }\end{array}$ & Time & Researcher \\
\hline $\begin{array}{l}\text { Handy size } \\
\text { product tanker }\end{array}$ & 3 & $\begin{array}{l}\text { Two ballast } \\
\text { voyages and one } \\
\text { laden voyage }\end{array}$ & $\begin{array}{l}\text { Gdánsk-Ventspils- } \\
\text { Bremen-Kiel } \\
\text { Holtenau }\end{array}$ & 14 & April & \\
\hline $\begin{array}{l}\text { Panamax } \\
\text { product tanker }\end{array}$ & 3 & $\begin{array}{l}\text { Two loaded } \\
\text { voyages and one } \\
\text { ballast }\end{array}$ & $\begin{array}{l}\text { Colon-Panama City- } \\
\text { Colombia (SBM)- } \\
\text { New Orleans }\end{array}$ & 2018 & Poulsen \\
\hline
\end{tabular}

Interview-guide for chartering, operations and technical managers in tanker shipping companies June-August 2018

In our e-mail approach to the interviewees, we explained our interest in the potential for reduction of GHG emissions from shipping. We explained that our research concerned the question of how shipping can achieve the GHG goals agreed at the IMO MEPC meeting in April 2018. We revealed the following two questions below (but not more than that):

1. What is the potential for time savings in tanker operations (in port and at anchorage)? Could reduce turn-around time in port and reduced time at anchorage enable ships to slow-steam further and achieve emission abatement?

2. What is your view on the GHG data collection systems from the EU (MRV) and the IMO (DCS)?

The second part of the interview guide contained questions pertaining to the new data collection systems on GHG (MRV and DCS). Those questions pertain to a second study, which will be published in a separate paper.

The interviews were semi-structured. We targeted heads of chartering, operations and technical departments in tanker shipping companies (crude oil, product, chemical, LPG, and LNG). The interviews will fall in two parts:

1. Time savings potential, because this question is focused on the shipping companies' own operations.

2. The MRV and DCS discussions, because they are both concerned with shipping companies' own operations and environmental regulation. We expected the latter aspect to be more controversial in the view of the interviewees than the discussion on time savings.

The overall structure of the interviews was the following:

1. Start with open-ended questions: Please describe what you do. How you do it? How does regulation affect your company? 
2. Gradually follow up with more testing questions: Did you consider the following aspects and factors? If you see an improvement potential, why has this potential not already been achieved? How can shipping achieve significant GHG emission reductions?

3. Ending with clarifying questions about the business model of the shipping company: What are your competitiveness factors? (In order to supplement the information which is available in company annual reports and on corporate website).

\section{PART 1 - POTENTIAL FOR TIME SAVINGS}

Do you see a potential for time savings in the operation of tankers, which could allow for service speed reductions?

- If yes, where?

$\circ$ How large is the potential?

- How to achieve it?

- Why has it not been achieved already?

- If not, why not?

\section{Port turn-around time}

- What are the factors, which influence a ship's turn-around-time in port?

$\circ$ Do you see variation in the duration of port calls?

- If yes, what in your experience is the shortest and what is the longest?

- What causes such variation?

- What are the main activities during a tanker's port call?

- Could you please describe the different activities and processes that take place during a tanker's port call?

- How long time does each activity take?

- Which of these activities is the crew or the shipping company in control of?

- How do bunkering, provisioning, garbage and sludge handling, crew changes or other activities influence the time spent in port?

- Would it be possible to save time on any of the activities?

- Which and how?

- How can achieve such time saving measures?

- How do customs clearance, immigration, signing of bills of lading etc. influence the time spent in port?

- Port turn-around time saving measures

- What can you, in the chartering (or operations) department of a tanker shipping company do to reduce port turn-around time?

- Do you have experiences with this?

- What can seafarers onboard the ships do to reduce time in port?

- Who are the other key stakeholders, who can ensure short turn-around time in port? 


\section{Time spent at anchorage}

- Do any of your ships spend time in laden condition at anchorages, while waiting for berth?

o If yes:

- Where?

- Is there any difference in the waiting time between different geographies, terminals or ports?

- If yes, what causes this variation?

- For how long do the ships wait?

- Is waiting time at anchorage affected by the ship's charter party? Or type of charter (voyage vs. time charter)?

- Does waiting time at anchorage affect your earnings in any way?

- Under voyage charters?

$\circ$ When will you start earning demurrage?

- Does demurrage rate differ from the voyage charter rate?

- If yes, how and why?

- Under time charters?

- Can you minimize or avoid the waiting time?

- Would you want to do that?

- What would be required to minimize waiting time?

- Virtual arrival schemes

- Do you use virtual arrival schemes in your company today?

- If yes, where and when?

- Do you propose to charterers to use virtual arrival clauses to your voyage charterers?

- If not, why not?

- Do you have experiences with virtual arrival schemes from the previous shipping companies that you worked in?

- Would implementation of virtual arrival clauses not enable shipping to reduce its fuel consumption and achieve emission abatement?

- Are you familiar with the BIMCO virtual arrival clause for voyage charters, which was developed in 2012?

- What is your view on the clause?

- Do you use it? Or offer your charterers to use?

- If yes, who use it?

$\circ$ And how frequently is it used?

- If not, why not?

- Do you see a potential for implementation of virtual arrival schemes?

- If yes, what would it require?

- And who should be involved for it to succeed?

\section{PART 2 - DATA SETS ON GHG EMISSIONS}




\section{Shipping company performance monitoring system}

- How do you measure the fuel consumption of your ships?

- Which onboard energy consumers do you focus on?

○ Do you use noon reports?

$\circ$ Do you use auto-logging systems?

- Do you have flow meters onboard?

- How frequently do you collect data?

- What do you use the data from the systems for?

- Have you changed your systems in recent years?

- What are the key factors, which influence a ship's fuel consumption?

- Which of these factors do you have an influence on?

\section{View on EU MRV}

- How does the EU MRV affect the work you do and your shipping company?

- How do you collect data for MRV?

- Which data do you collect?

- Where do you collect the data from?

- Who collects the data?

- Resources for MRV data collection

- Who is responsible for MRV data collection in your company?

- Did you allocate additional resources to the data collection process, in terms of:

- Human resources,

- New IT-infrastructure, or

- Monitoring equipment onboard the ships in your fleet?

- How much does the MRV data collection require of your company in terms of man-hours per year/human resources?

- To comply with EU MRV did you need to make any changes in the collection of fuel consumption data from your fleet (i.e., amend or revise your vessel performance monitoring systems)?

- If yes, which, how and why?

- Did you use consultants or other external experts for the design or implementation of your MRV data collection system?

- How do you quality control your MRV data?

- Who is verifying your MRV data?

- How does verification take place?

- How frequently does it take place?

- Can you use the process of data verification to improve your data quality?

- How does company's fleet performance monitoring system compare with the data collection for the MRV and DCS systems?

\section{View on IMO DCS}

- How do you collect data for the IMO DCS? 
- Which data do you collect?

- Where do you collect the data from?

- Who collects the data?

- How frequently do you collect data?

- Could you please compare the IMO DCS and the EU MRV?

$\circ$ What are the key differences between the two systems?

- Do these differences affect your work or data collection in any way?

$\circ$ Do you see any differences between the systems in terms of data quality?

- If yes, where and why?

\section{Internal use of MRV and DCS data}

- How do you use MRV and DCS data within your shipping company?

- For what purposes? Why?

- Can you use the MRV data to identify a potential for energy efficiency or other types of improvement potentials within your fleet?

- Can you use the MRV or DCS data to identify fuel inefficient ships in your fleet?

- Have you actually done so?

- To what extent can you and your colleagues in the shipping company affect the efficiency measurements in the MRV and DCS systems?

- Can you make changes in the operations of your ships, which would improve the performance measurements of your ships in the MRV and DCS systems?

- If yes, how?

- If no, why not?

- Do the MRV or DCS data convey the same message with regard to the efficiency of individual ships?

- If not, what are the causes for the observed differences?

- Do the MRV and DCS systems reflect the true performance differences between individual ships?

- Do the MRV and DCS data sets align with the performance metrics that you use in your internal fleet performance monitoring system?

- If yes, what are the key performance metrics?

- If not, why not?

\section{External use of MRV and DCS data}

- Who do you expect to use the MRV and DCS data, when data sets become publicly available?

$\circ$ Will charterers use them for chartering decisions?

- Can they identify the most fuel efficient ships in the market?

- Will you or your company use the data sets, when chartering ships?

- Can you use the MRV or DCS data sets for guiding your own chartering decision?

- Could other stakeholders have an interest in using the MRV data?

- Who? Why?

- For instance:

- Port authorities (for green port fee reductions)? 
- Policy makers?

- For implementation of Market-Based Measures in the future?

$\circ$ What is your view on MBMs?

- Journalists?

- NGOs?

- Others?

- Does the MRV or DCS systems provide you with any business opportunities?

- Does the MRV or DCS force you to reveal commercially sensitive information?

- If yes, which information?

$\circ$ And what effects do you foresee from MRV and DCS?

Link between MRV, DCS and private eco-rating schemes

- $\quad$ Are you familiar with private eco-ratings in shipping?

○ If not: CCWG, CSI, ESI, Rightship, BetterFleet, EVDI

If yes, which ones?

- Do you use them?

- If yes, what for?

- Do you know of other using it?

- How do the eco-ratings affect the work you do, your company and the business of tanker shipping more broadly?

- From you point of view, how do the MRV, DCS and the private eco-rating schemes (CCWG, ESI, CSI, Green Award, Rightship/EVDI and BetterFleet) compare?

$\circ$ Are they measuring the same factors?

$\circ$ Or are there important differences between any of the ratings?

- If yes, which?

0 Are there any overlaps between the private eco-ratings and the MRV and DCS systems?

- If yes, which?

- In your opinion, which of the systems provide the best measurement of a ship's energy efficiency?

- And of its overall environmental performance?

- Do cargo-owners ask you questions regarding your $\mathrm{CO} 2$ emissions or any other aspects of your environmental footprint?

If no, why not?

- If yes, what do they ask?

- And who asks?

- What do they use the information for?

View on the air emission regulation in shipping

- What is your view on regulation of air emissions in shipping?

$\circ$ Regulation from the IMO? The EU? And others?

- How is regulation affecting your business and your company?

- What regulation is affecting you the most? 
- How is regulation on air pollutants and regulation on GHG affecting your company? And the shipping markets?

- What are the costs associated with compliance for you?

- In your opinion, how can shipping achieve the GHG emissions reductions agreed the April 2018 MEPC by 2050 (i.e. a 50 per cent reduction in absolute GHG emission levels relative to 2008)?

- To what extent can these ambitions be achieved through efficiency improvements in the shipping sector?

- In your opinion, does shipping need a new type of fuel to achieve the goals?

- From you point of view, why did the MRV and DCS systems come into existence?

\section{Shipping company strategy}

- In addition to the information available on your web-page and in your annual report, so short follow up or clarifying questions about :

- Which trades are you active in?

$\circ$ In terms of geography?

$\circ$ In terms of vessel sizes?

- In terms of contract types and contract durations?

- Use of spot, time charter, bareboat charters and Contracts of Affreightments?

$\circ$ Do you engage in asset play?

- Do you contract newbuildings or buy second-hand vessels?

- How are ships managed? In-house or outsourced set-up for:

- Chartering

- Operations

- Technical management

- Crewing

- Why? What is the motivation behind this set-up?

- What are the key sources of competitiveness for your company? 